\title{
Flame spread on the pitched roof covering from a single ignition source
}

\author{
Marina Gravit ${ }^{1}$, Evgenii Polishchuk $^{2}$, Ivan Dmitriev ${ }^{1}$, Mariya Shakhova ${ }^{1, *}$ \\ ${ }^{1}$ Peter the Great St. Petersburg Polytechnic University, 29 Polytechnicheskaya, Saint Petersburg, \\ 195251, Russia \\ ${ }^{2}$ TechnoNICOL Corporation, 47 Gilyarovskogo, Moscow, 129110, Russia
}

\begin{abstract}
The aim of this work is to conduct the assessment of the development of a fire on a waterproofing carpet as a result of exposure to a low-power ignition source outside the roof structure. In this article, tests were carried out according to the method of CEN/TS 1187:2013, Test 2 and Test 3 to determine the fire hazard of a roofing composition with a wooden frame and a coating, which consist of shingle «TECHNONICOL», galvanized steel profiled sheet and steel waterproofing layer with polymer coating. According to the results of the tests, the roofs with shingle are practically not inferior to similar roof structures with a coating of metal sheets in terms of fire safety. The test results showed that despite the presence of combustible materials in the composition, certain structural solutions allow to obtain class Broof (t2) (mean damaged length of the roof covering and substrate $\leq 0.550 \mathrm{~m}$ at $2 \mathrm{~m} / \mathrm{s}$ wind speed) and Broof (t3) (time for external fire spread to the edge of the measuring zone $\mathrm{TE} \geq 30 \mathrm{~min}$ and time to fire penetration $\mathrm{Tp} \geq 30 \mathrm{~min}$ ). However, these tests are not related to large scale reference tests.
\end{abstract}

\section{Introduction}

The pitched roofs are relevant for the most residential buildings in low- and mid-rise construction (Fig. 1). Such coatings are also characteristic of buildings in the historical centers of many cities and they periodically need reconstruction [1].

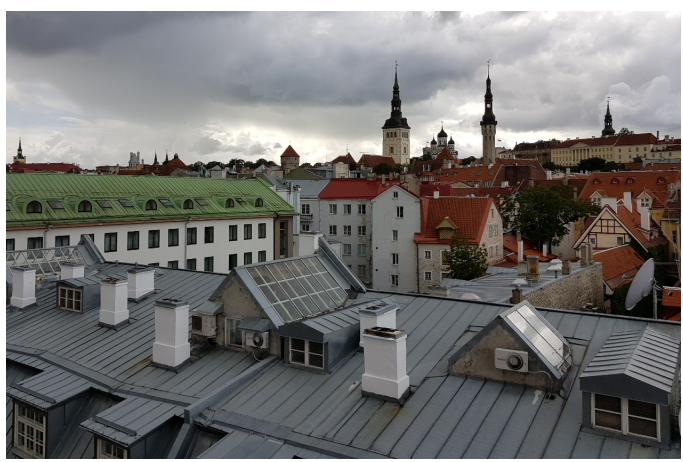

Fig. 1. The pitched roof in Tallinn. 
Many registered cases of fire in various buildings arise due to the ignition of roofing. It is important that the flame does not spread on the surface and penetrate to the building inside, as further development of the fire can lead to the collapse of the supporting structures. To this end, a lot of research has been conducted in the world literature to assess the fire hazard of roof structures. Comprehensive studies of the fire characteristics of roofs were carried out, for example, for a large space exhibition center (the non-uniform fire temperature fields for the designed fire scenarios have been generated by using Fire Dynamic Simulator (FDS)) [2]; for the cylindrical roof with elements connected by punched metal plates [3]; for the airport terminal steel structure (used the fire dynamics software FDS) [4]; for the one-storey glued load-bearing timber framework for sports hall of Corporative University of Sberbank [5]. In the research project [6] the structural fire prevention for large scale wooden roof structures under parametric fire exposure investigated. In this paper, the effect of flame spread at exposed lining and inside the elements.

To implement such studies, various methods are used. For example, in the paper [7] discusses the approach is based on the extraction of a special set of effective material properties from bench-scale experimental data. These properties are then used in FDS simulations of flame spread in intermediate-scale flammability tests. The basis the paper [8] is to present a comparison of results from full-scale roofing assembly experiments, to mock-ups. In the paper [9], a series of steel roof truss models are established by using ANSYS software, and the behaviour of truss exposed to localized fire is studied. Many other studies have also been done through numerical simulations of roofs [10-16].

Carrying out such studies allows us to analyze the behavior of building structures during a fire and to develop technical and technological conception for roofs.

For the construction of new and reconstruction of old roofs, it is necessary to apply new technological materials, since traditional ones do not always meet modern needs, such as energy efficiency, environmental friendliness, resistance to atmospheric influences, and long, non-repairable life. However, the implementation of the construction of modern roofing materials and design conceptions for roofs using wood and its modifications (CLT and Glulam) [17-18] and polymeric materials [19] is limited by the existing regulatory requirements in the field of fire safety. The existing limitations are explained by the multivariance of the impact during the development of a fire, which cannot be evaluated within the framework of a unified test procedure.

There are many different test methods, some are developed by national standardisation organisations such as ASTM in the US or DIN in Germany while others are developed by the insurance industry. Some of the existing test methods focus only on surface spread of flame on the top of the roof, others address both surface spread of flame and penetration of fire from above, as well as the issue of fire spreading through the roofing system when exposed to a fire from within the building [20].

To determine the fire behaviour of roofs, appropriate fire test methods are needed. For each test method the results are linked to the fire scenario, which the test method is attempting to simulate [21-24].

Studies of the fire hazard of roof structures in conditions as close as possible to a real fire are relevant and promising. The complex of studies should include both an assessment of the fire hazard of materials of a waterproofing carpet, the occurrence of a fire on which may occur when pyrotechnic devices get in, and an assessment of the effect of structures and materials of a roof on the danger of occurrence and spread of fire in the attic volume, as well as the exit of a fire to a roof slope.

The aim of this work is to conduct one of the stages of a comprehensive study, namely, the assessment of the development of a fire on a waterproofing carpet as a result of exposure to a low-power ignition source outside the roof structure. 


\section{Methods}

In the national standard EN 13501-5 provides the fire performance classification procedures for roofs/roof coverings exposed to external fire based on the four test methods given in CEN/TS 1187:2013 and the relevant extended application rules.

Standard CEN/TS 1187 «Test methods for external fire exposure to roofs» is used to classify fire safety as a waterproofing roofing carpet, and the roofing composition as a whole. Four test methods are used:

Test 1: Method with burning brands.

Test 2: Method with burning brands and wind.

Test 3: Method with burning brands, wind and supplementary radiant heat.

Test 4: Three stage test method incorporating burning brands, wind and supplementary radiant heat.

\subsection{CEN/TS 1187:2013, Test 2}

Tests were conducted to determine the fire hazard of the roofing composition was carried out according to the method of CEN/TS 1187:2013, Test 2. The test simulates a roof exposed to a burning brand only and with an imposed airflow over the roof of either $2.0 \mathrm{~m} / \mathrm{s}$ or $4.0 \mathrm{~m} / \mathrm{s}$.

The ignition source is a $40 \mathrm{~g}$ wood crib dimensions $10 \mathrm{~mm} \times 10 \mathrm{~mm} \times 100 \mathrm{~mm}$. The burning wood crib is positioned centrally on the specimen and with its centre $100 \mathrm{~mm}$ from the lower edge of the specimen.

The test is terminated:

- 15 minutes form the time the burning wood crib was positioned on the test specimen;

- when the flame front has reached the upper edge of the specimen.

The following observations shall be made:

- the length of the damage material of the roof covering and the substrate measured from the centre of position of the wood crib.

- damaged area in square $\mathrm{mm}$ of the roof covering and substrate respectively and the maximum depth of the damage on the specimen in $\mathrm{mm}$.

The test specimens are $1000 \mathrm{~mm}$ long and $400 \mathrm{~mm}$ wide. Tested three specimens:

No. 1. - OSB-3.9 mm

- backing material «ANDEREP PROF», $1.9 \mathrm{~mm} \pm 0,1 \%$ (combustibility - level 4, ignitability - 3, spread flame - 4 according to Russian test methods)

- shingle «TECHNONICOL SHINGLAS», $3.0 \pm 0.2 \mathrm{~mm}$ (combustibility - level 4, ignitability -2 , spread flame - 1 according to Russian test methods)

No. 2. - OSB-3.9 mm

- backing material «ANDEREP PROF», $1.9 \mathrm{~mm} \pm 0.1 \%$ (combustibility - level 4, ignitability - 3, spread flame - 4 according to Russian test methods)

- composite shingle «TECHNONICOL SHINGLAS», $5.4 \pm 0.2 \mathrm{~mm}$

No. 3. - wooden bar $20 \times 30 \mathrm{~mm}$

- shingle «TECHNONICOL LUXARD», $2.5 \pm 0.5 \mathrm{~mm}$

\subsection{CEN/TS 1187:2013, Test 3}

Tests of fragments of a roofless roof covering were conducted for compliance with class Broof ( $\mathrm{t} 3$ ) to the method of CEN/TS 1187:2013, Test 3. The test simulates a roof exposed to a burning brand as well as radiation and with an imposed airflow over the roof of 3.0 $\mathrm{m} / \mathrm{s}$. 
The burning brand consist of $82 \mathrm{~g}$ wood crib and soaked in Heptane. The brands shall be positioned with their centres $500 \mathrm{~mm}$ from the lower edge of the specimen and $370 \mathrm{~mm}$ apart and equidistant from the specimen longitudinal centre line.

The radiation is provided by a radiant panel positioned in a plane parallel to the surface of the specimen and at $500 \mathrm{~mm}$ providing a heat flux of $12.5 \mathrm{~kW} / \mathrm{m}^{2}$. The specimen is exposed to radiant heat for 3 minutes before the burning brands are placed.

The test is terminated:

- Fire spreads on the underside of specimen after penetration.

- 30 minutes has passed since beginning of the test.

- Risk of safety to personnel or impending damage to the equipment.

The following shall be observed:

- Progress of sustained flaming at the base (and not at the 'flame envelope'),

- The time when the sustained flaming has reached 100, 300, 500, 700, 900, 1,100,

$1,300,2,000 \mathrm{~mm}$ from the edges of the brands and upper edge of measuring zone.

- Time where sustained flaming has progressed downwards 100, 300, $500 \mathrm{~mm}$.

- Time of burning droplets or debris.

- Penetration and internal damage.

- $\mathrm{T}_{\mathrm{E}}=$ Time for external fire spread to the edge of the measuring zone.

- $\mathrm{T}_{\mathrm{p}}=$ Time to fire penetration.

The test specimens are 3,000 $\mathrm{mm}$ long and 1,200 mm wide. Tested three specimens:

No. 1. - timber frame

- OSB-3

- backing material «ANDEREP PROF» (combustibility - level 4, ignitability - 3, spread flame - 4 according to Russian test methods)

- shingle «TECHNONICOL SHINGLAS», $3.0 \pm 0.2 \mathrm{~mm}$ (combustibility - level 4, ignitability - 2, spread flame - 1 according to Russian test methods)

No. 2. - timber frame

- counter batten from boards

- galvanized steel profiled sheet (combustibility - level 1, spread flame - 1 according to Russian test methods)

No. 3. - timber frame

- OSB-3

- steel waterproofing layer with polymer coating $0.4 \mathrm{~mm}$ (combustibility - level 1 , spread flame - 1 according to Russian test methods)

Testing is shown in Figure 2.
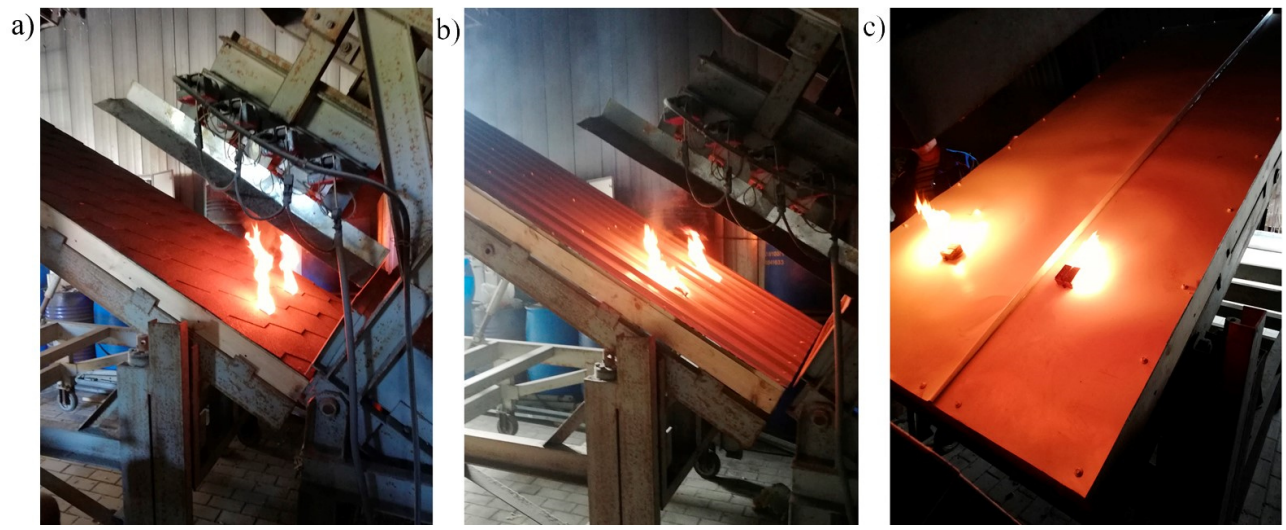

Fig. 2. a) fragment No.1; b) fragment No.2; c) fragment No.3. 
The table 1 shows classes of external fire performance for roofs coverings tested to CEN TS1187.

Table 1. Classes of external fire performance for roofs coverings tested to CEN TS1187.

\begin{tabular}{|c|c|c|}
\hline Test & Class & Classification criteria \\
\hline \multirow[t]{2}{*}{2} & $\mathrm{~B}_{\mathrm{ROOF}}(\mathrm{t} 2)$ & $\begin{array}{l}\text { For both test series at } 2 \mathrm{~m} / \mathrm{s} \text { and } 4 \mathrm{~m} / \mathrm{s} \text { wind speed: } \\
\text { - } \quad \text { mean damaged length of the roof covering and substrate } \leq 0.550 \\
\mathrm{~m} \text {; } \\
\text { - } \quad \text { max. damaged length of the roof covering and substrate } \leq 0.800 \\
\text { m. }\end{array}$ \\
\hline & $\mathrm{F}_{\mathrm{ROOF}}(\mathrm{t} 2)$ & No performance determined \\
\hline \multirow{4}{*}{3} & $\mathrm{~B}_{\mathrm{ROOF}}(\mathrm{t} 3)$ & $\mathrm{T}_{\mathrm{E}} \geq 30 \min$ and $\mathrm{T}_{\mathrm{p}} \geq 30 \mathrm{~min}$ \\
\hline & $\mathrm{C}_{\mathrm{ROOF}}(\mathrm{t} 3)$ & $\mathrm{T}_{\mathrm{E}} \geq 10 \mathrm{~min}$ and $\mathrm{T}_{\mathrm{p}} \geq 15 \mathrm{~min}$ \\
\hline & $\mathrm{D}_{\mathrm{ROOF}}(\mathrm{t} 3)$ & $\mathrm{T}_{\mathrm{p}} \geq 5 \min$ \\
\hline & $\mathrm{F}_{\mathrm{ROOF}}(\mathrm{t} 3)$ & No performance determined \\
\hline
\end{tabular}

\section{Results and discussions}

The test results showed that despite the presence of combustible materials in the composition, certain structural solutions allow to obtain class Broof (t2) (Table 2).

Table 2. Test results to the method of CEN/TS 1187:2013, Test 2.

\begin{tabular}{|c|c|c|c|c|c|c|c|c|c|}
\hline \multirow[t]{2}{*}{ No. } & \multirow[t]{2}{*}{ Parameter } & \multicolumn{2}{|c|}{ Criterion } & \multicolumn{5}{|c|}{ Test results, mm } & \multirow{2}{*}{$\begin{array}{l}\text { Con- } \\
\text { for- } \\
\text { mity }\end{array}$} \\
\hline & & Mean & Max & 1 & 2 & 3 & Mean & Max & \\
\hline \multirow{2}{*}{1} & $\begin{array}{l}\text { Damaged } \\
\text { length of the } \\
\text { roof covering at } \\
2 \mathrm{~m} / \mathrm{s} \text { wind } \\
\text { speed }\end{array}$ & $\leq 0.550 \mathrm{~m}$ & $\leq 0.800 \mathrm{~m}$ & 160 & 145 & - & 103 & 112 & $\begin{array}{c}\text { Broof } \\
(\mathrm{t} 2)\end{array}$ \\
\hline & $\begin{array}{l}\text { Damaged } \\
\text { length of the } \\
\text { roof substrate at } \\
2 \mathrm{~m} / \mathrm{s} \text { wind } \\
\text { speed }\end{array}$ & $\leq 0.550 \mathrm{~m}$ & $\leq 0.800 \mathrm{~m}$ & 0 & 0 & - & 0 & 0 & $\begin{array}{c}\text { Broof } \\
(\mathrm{t} 2)\end{array}$ \\
\hline \multirow{2}{*}{2} & $\begin{array}{l}\text { Damaged } \\
\text { length of the } \\
\text { roof covering at } \\
2 \mathrm{~m} / \mathrm{s} \text { wind } \\
\text { speed }\end{array}$ & $\leq 0.550 \mathrm{~m}$ & $\leq 0.800 \mathrm{~m}$ & 140 & 125 & - & 103 & 112 & $\begin{array}{c}\text { Broof } \\
(\mathrm{t} 2)\end{array}$ \\
\hline & $\begin{array}{l}\text { Damaged } \\
\text { length of the } \\
\text { roof substrate at } \\
2 \mathrm{~m} / \mathrm{s} \text { wind } \\
\text { speed }\end{array}$ & $\leq 0.550 \mathrm{~m}$ & $\leq 0.800 \mathrm{~m}$ & 0 & 0 & - & 0 & 0 & $\begin{array}{c}\text { Broof } \\
(\mathrm{t} 2)\end{array}$ \\
\hline \multirow[t]{2}{*}{3} & $\begin{array}{c}\text { Damaged } \\
\text { length of the } \\
\text { roof covering at } \\
2 \mathrm{~m} / \mathrm{s} \text { wind } \\
\text { speed }\end{array}$ & $\leq 0.550 \mathrm{~m}$ & $\leq 0.800 \mathrm{~m}$ & 0 & 0 & - & 0 & 0 & $\begin{array}{c}\text { Broof } \\
(\mathrm{t} 2)\end{array}$ \\
\hline & $\begin{array}{c}\text { Damaged } \\
\text { length of the } \\
\text { roof substrate at }\end{array}$ & $\leq 0.550 \mathrm{~m}$ & $\leq 0.800 \mathrm{~m}$ & 0 & 0 & - & - & - & $\begin{array}{c}\text { Broof } \\
(\mathrm{t} 2)\end{array}$ \\
\hline
\end{tabular}




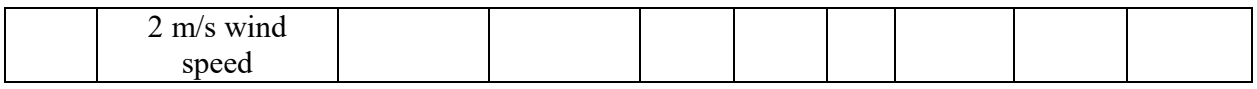

An important role in the roofing composition is played by the fire hazard of the material of the roof waterproofing carpet. For example, when using a shingle based on fiberglass with basalt powder or composite shingle on the basis of a steel sheet with basalt powder, the flame does not spread over the surface, and even a combustible backing material is destroyed only at the place of fire exposure, within the permissible regulatory limits of the classification of the method.

The test according to method CEN/TS 1187:2013, Test 3 was carried out on a fragment on a combustible base (wooden frame and OSB-3 or counter batten from boards), however, all samples confirmed compliance with class Broof (t3) and no through burning was observed (Table 3).

Table 3. Test results to the method of CEN/TS 1187:2013, Test 3.

\begin{tabular}{|c|c|c|c|c|}
\hline No. & Conformity & Specimen & $\begin{array}{c}\text { Time for external fire } \\
\text { spread to the edge of the } \\
\text { measuring zone } \mathrm{T}_{\mathrm{E}}, \mathrm{min}\end{array}$ & $\begin{array}{c}\text { Time to fire } \\
\text { penetration } \mathrm{T}_{\mathrm{p}}, \\
\text { min }\end{array}$ \\
\hline \multirow{2}{*}{1} & \multirow{2}{*}{ Broof (t3) } & 2 & 30 & - \\
\hline \multirow{2}{*}{2} & \multirow{2}{*}{ Broof (t3) } & 1 & 30 & - \\
\hline \multirow{2}{*}{3} & \multirow{2}{*}{ Broof (t3) } & 2 & 30 & - \\
\cline { 3 - 5 } & & 2 & 30 & - \\
\hline
\end{tabular}

According to the results of the tests, it is clear that roofs made on a combustible base (OSB), with a combustible backing material and a combustible coating of shingle can provide a sufficiently high level of protection, both against the occurrence of a fire, under the influence of single sources of ignition (CEN/TS 1187:2013, Test 2), and from its spread, in conditions of combined exposure to sources of radiation and with an imposed airflow over the roof (CEN/TS 1187:2013, Test 3). According to the results of the tests, we can say that roofs with shingle are practically not inferior, in terms of fire safety, to similar roof structures, but with a coating of metal sheets.

This test methods more closely resemble flame spread tests on the roof covering, than a test of the performance of the entire roof assembly. The tests designed such that the influence of the combustibility of the layers below the roof covering do not play a significant role in the fire performance under test. Currently, the test CEN TC1187 test 4 is the only test to consider the influence of the internal layers, but only related to penetration and not fire spreading over the roof. The problem with these tests is that even though they try to simulate the different types of heat exposure and ignition sources, they are not related to linked to large scale reference test. There exists at this point no large scale reference test for external exposure to roofs [15].

\section{Conclusions}

Fire safety of roofs should be considered for a complex of possible impacts. Currently, the available test results only consider the development of a fire at the top of the roof, it is planned to conduct tests taking into account the development of fire in the attic volume, with the spread of fire along the rafter system and the base under the roof; exit of an internal fire to the roof, followed by the spread of burning along the ramp. 


\section{References}

1. R. Miniotaite, ISEC. 8, 1253-1258 (2015).

2. L. Lu, G. Yuan, Z. Huang, Q. Shu, Q. Li, Fire Saf. J. 93, 21-38 (2017).

3. T. Saknite, D. Serdjuks, V. Goremikins, L. Pakrastins, N. I. Vatin, Magazine of Civil Engineering. 64, 26-39 (2016).

4. H. X. Wang, X. X. Zha, M. Yu, H. Y. Wang, J. Harbin, Inst. Technol. 43, 26-30 (2011).

5. M. V. Gravit, D. Serdjuks, A. V. Bardin, V. Prusakov, K. Buka-Vaivade, Magazine of Civil Engineering. 85, 92-106 (2019).

6. V. Hofmann, N. Werther, S. Winter, WCTE. (2014).

7. S. B. Dorofeev, Conf. Proc. Fire Mater. 12, 321-332 (2011).

8. S. Suzuki, S. L. Manzello, Fire Saf. J. 91, 784-790 (2017).

9. S. Lin, Y. Du, Y. Jiang, J. Fu, Prog. Steel Build. Struct. 17, 57-64 (2015).

10. P. G. Papadopoulos, A. K. Papadopoulou, K. K. Papaioannou, Struct. Eng. Mech. 29, 37-53 (2008).

11. B. Merci, K. Van Maele, Fire Saf. J. 43, 495-511 (2008).

12. J. Li, Q. Li, Y. Dong, C. Li, Applied Mech. and Mat. 224, 418-421 (2012).

13. J. Li, Q. Li, Y. Dong, Advan. Mater. Res. 538, 989-992 (2012).

14. Y. Bai, Y. J. Shi, Y. Q. Wang, Eng. Sci. Ed. 38, 19-23 (2006).

15. O. Tlili, H. Mhiri, P. Bournot, Int. J. Therm. Sci. 90, 135-149 (2015).

16. M. Gravit, Y. Simonenko, A. Larionov, E3S Web of Conf. 91, 02049 (2019).

17. V. Hofmann, N. Werther, S. Winter, Bautechnik. 94, 389-398 (2017).

18. T. Domanski, Glob. Think.Struct. Eng.: Rec. Ach. (2012).

19. M. Khan, R. Alpert, G. Smith, ASTM Int. 37-16 (2008).

20. B. Messerschmidt, J. Scott, Fire Mater. 13, 35-46 (2013)

21. A. H. Yi, Z. Yang, W. J. Lin, J. Y. Liu, X. Zhao, Procedia Eng. 52, 544-547 (2013).

22. S. L. Manzello, Y. Hayashi, T. Yoneki, Y. Yamamoto, Fire Saf. J. 45, 35-43 (2010).

23. S. Suzuki, D. Nii, S. L. Manzello, Fire Mater. 41, 84-96 (2017).

24. I. Boko, N. Toríc, B. Peroš, ICOSSAR. 4361-4366 (2013). 